\title{
Foreign Policy: Public Opinion and Political Legacy
}

\author{
Aaron T. Walter ${ }^{1}$
}

To the degree that public opinion, as domestic variable, influences a leaders decision-making in the area of foreign affairs is significant. Political leaders use public opinion polling to support government position or in attempts to mold policy position(s) in the affirmative. The following article investigates how public opinion affects U.S. presidential foreign policy decisions and to the degree those decisions are the base for political legacy. The theoretical argument is that domestic variables and leaders decisions often act in mutual support of each others in complemen-tary interests and when not the case, it is the leader whose agenda setting or creating a frame impacts public opinion.

Keywords: leader, masses, public opinion, foreign policy, political legacy.

Do tej miery, že verejná mienka, ako domáci premenná , ovplyvňuje vodcovia rozhodovanie $v$ oblasti zahraničných vecí je významná . Politickí vodcovia využívania verejnej mienky k podpore vládnej pozícii, alebo $v$ pokusoch plesní polohy politiky v kladne. Nasledujúci článok skúma, ako verejná mienka ovplyvňuje americkej prezidentskej zahraničné politické rozhodnutia , a do tej miery, tieto rozhodnutia sú základom pre politické dedičstvo. Teoretický argument je, že domáci premenné a ich vodcovia rozhodnutia často konajú vo vzájomnej podpore každé iné v doplnkový záujem a ked' nie je tento prípad, je to vodca , ktorého nastavenie alebo vytvorením dopadom na rám verejnú mienku agenda.

Klúčové slová: vodcu, masy, verejná mienka , zahraničná politika , politické dedičstvo .

\section{Introduction}

This paper attempts to explain the relationship between public opinion i.e. masses and the foreign policy of a liberal democracy articulated by its leadership. I will argue that the policy impact of public opinion does depend on issues or particular patterns of public attitudes and the domestic structure and the building a political legacy for a leader. This paper analyzes the effort by the United States to construct a nuclear agreement with Iran since 2009. The analysis of the interaction between public opinion and presidential decision making reveals that the policy outcome may differ, but domestic structure remains as does the pursuit of personalized political legacy.

1 Aaron T. Walter, Ph.D., Department of Politics and European Studies, Faculty of Social Sciences, Ss. Cyril \& Methodius University, Bucianska 4/A, 917 01, Trnava, Slovakia. E-mail: aaronwalter@gmail.com 
In discussing public opinion and foreign policy there are both theoretical concepts and methodological problems. Namely, to whom follows who? The available literature on the interaction between public opinion and government i.e. president in the foreign policy making process may be categorized according to two broad concepts. ${ }^{2}$ According to pluralist theory of democracy, a 'bottom-up' approach indicates that the general public has a measurable, in fact, a distinct impact. However, empirical counter evidence shows the difficulty in reconciliation of this bottom up concept since in Western Europe and the U.S. both leaders and masses hold similar support for basic goals of foreign policy. ${ }^{3}$ Still, there are cases where crucial foreign policy decisions have occurred without public opinion. Examples are U.S. permanent involvement in the security affairs of Europe or specifically the rapprochement policy between the U.S. and China in 1972.

Therefore, a second approach represented is the "top-down" process where the decision making is held with leaders. A viewpoint in concurrence with a realist approach to foreign policy. This view is held due to three factors because 1) low significant of the foreign policy issue, 2) low degree of knowledge about the issues involved or 3) volatility of public opinion. On these points however exist empirical evidence that questions such assumptions. First, large portions of the public regularly follow media reporting on foreign policy ${ }^{4}$, and while domestic concerns typically outweigh foreign issues, there is substantial consideration of foreign affairs amongst the public. ${ }^{5}$ Also, public attitudes on basic foreign policy issues appear more stable than assumed, less open to manipulation. Finally, leaders attempt to manipulate public opinion through various methods of propaganda or "spin". ${ }^{6}$ So, from these empirical problems, both models suffer from conceptual shortcomings. Leaders and the public are treated as

2 See Philip Everst and Arthur Faber, "Public Opinion, Foreign Policy, and Democracy" World Politics. 43 (July, 1991), 479-512.

3 For Western Europe, see Richard Eichenberg, "Victory has many friends: U.S. public opinion and the use of military force. International Security. (2005) 30:140-77. For the U.S., see Ole R. Holsi and James N. Rosenau, "The Domestic and Foreign Policy Beliefs of American Leaders, ”Journal of Conflict Resolution 32 (June 1988), 248-94.

4 See John H. Aldrich et al., "Foreign Affairs and Issue Voting: Do Presidential Candidates 'Waltz before a Blind Audience'?" American Political Science Review 83, no.1 (1989), 123-141.

5 See Tom W. Smith, "The Polls: America's Most Important Problem, Part 1: National and International," Public Opinion Quarterly 49, no. 2 (1985), Hans-Bernd Brosius "Perceptual Phenomena in the Agenda Setting Process" International Journal of Public Opinion Research 21, no. 2 (2009), 139-164.

6 Robert Shapiro and Benjamin I. Page, "Foreign Policy and the Rational Public," Journal of Conflict Resolution 32, no. 2 (1988), 211-47. 
unitary actors. Though some scholars have begun to characterize public opinion not only as relatively stable but a consistent counterweight that policy makers should, take into consideration (Page \& Bouton 2006). Moreover, is the simply understanding that opinion and public interest groups may lead to changes, an indirect effect.

The question of the public's informational capacity is a crucial foundation underlying our understanding of the foreign policy marketplace. According to Baum Potter (2008) research suggests a "consensus around two key points: (a) Citizens are typically at a significant informational disadvantage vis-a vis leadership elites, and (b) they compensate by employing heuristic cues that allow them to make reasoned judgments with small amounts of information." So, what role, if any, public opinion actually plays in specific American foreign policy crises? Indeed, research suggests public opinion has influenced US policy toward Nicaragua (Sobel 2001), Somalia (Klarevas 2002), and Iraq (Larson \& Savych 2005). On the above stated conceptual shortcoming one may view public perception and foreign policy with a degree of leniency; specifically where nuclear weapons are treated with concern but tolerated for their deterrent value, provided effective arms-control structure and institutions are in place. How a national leader pursues a foreign policy towards nations that are actively pursuing a nuclear program i.e. U.S.-Iran will be explored below, but how negotiations on this point occurred is linked to changes within both American public and American leaders attitude and changes in the international environment.

\section{Domestic Structures and International Environmental Changes}

The decentralized foreign policy making structure in the United States offers the best guide to how negotiations between the U.S. and Iran on its nuclear program has been able to occur. The built-in tensions within the executive branch is properly documented. Also, the American Congress has authority over conduct of foreign policy. American society and to a degree then public opinion is observed along both class divisions and ideological cleavages with repercussions in foreign policy. The bifurcation of the American people as "militant" or "cooperative" internationalists is correlated to ideological divisions and in recent decades an increasing partisanship. ${ }^{7}$ It is important then to see to what degree the public may be divided on a foreign policy issue, for example the current negotiations between the P5+1 nations (simplified to the U.S.) and Iran. In the near term, the public tends to rally behind presidential foreign policy initiatives, thereby giving presidents considerable influence over public opinion (Mueller 1973, Brody 1991); over the longer term, a separate body of research (Sobel 2001, Baum 2004a, Canes-Wrone 2006) suggests that public opinion can constrain foreign policy. Such literature offers instructive examples of both i.e. George W. Bush

7 "Political Polarization in the American Public" PewResearchCenter. June 12, 2014. 
following the September 11, 2001 terrorist attacks, on the former, while a latter example might be Richard Nixon in Cambodia, 1970.

Important variations emerge when one recognizes that public opinion is not uniform. Gartner \& Segura (1998, 2000), for example, considered the effects of race in public opinion and Vietnam War casualties. Another element to consider is whether heterogeneity in public opinion varies over time. Jacobson (2006) explores the fragmentation of public opinion during the George W. Bush administration, concluding that President Bush created historic levels of partisan polarization in the electorate, especially regarding Iraq. These findings point to different segments of the public with differing informational disadvantages and as a consequence, willingness to agree to the messages distributed by the media from leaders. Still, public support tends to be more fragile when the public has less experience with the policy and requires greater information to understand and support. In such cases, (Baum and Potter, 2008:50) "the public may react quickly and negatively to the information produced..." or as CanesWrone (2006) argues that presidents typically appeal to public opinion on issues the public is likely to support, primarily when the leader advocate such issues. For example, presidents aim such appeals at gaining leverage vis-a' -vis Congress. On current foreign policy efforts such as Iran, Powlick \& Katz's (1998) activation model of the American public opinion/foreign policy nexus is instructive. Both Powlick \& Katz argue that public opinion is latent and inactive. This offers leaders a degree of independence in most circumstances to conduct policy as they prefer. However, Powlick \& Katz suggest that, under limited circumstances, foreign policy issues may "activate" public attention typically prompted by elite (leader) debate and major media coverage emphasizing frames compatible with standing public interests. As a domestic variable this public opinion was seen in Iraq from 2004-2009 and now in regards to Iran.

The U.S. public opinion when surveyed from 2006 through 2012 saw Iran as a threat though economic and diplomatic efforts rather than military options were preferred. ${ }^{8}$ Public threat perception translated into attitudes on how to deal with Iran support current administration efforts at reaching a nuclear agreement. Therefore the domestic variable of public opinion linked with presidential prerogative of power in foreign affairs impacts the international environment. The two are connected from President Barack Obama's 2008 campaign rhetoric and since 2009 agenda setting. On the latter it is instructive to observe the 2011 and 2012 State of the Union Address. ${ }^{9}$

The setting of American foreign affairs in the Middle East since 2010 has been largely of balancing regional powers and directly confronting Islamic terrorism. As previously noted the American president has immense power in the realm of foreign

8 See USAToday/Gallup poll 2006, Chicago Council on Global Affairs poll 2012, and Reuters/Zogby poll 2010 and 2012.

9 See 2011 and 2012 State Of Union Address before joint sessions of U.S. Congress. 
policy and therefore on the issue of pursuing a long-term agenda item the American president looks to both historical precedence and personal future couched in popular term, 'legacy'. For President Obama after 2012, the domestic variable of public opinion has largely been molded by the president no longer constrained by reelection efforts. As noted in the first half of section one, public tends to rally behind presidential foreign policy initiatives, giving presidents considerable influence over public opinion. As such, the American public are presently cooperative internationalists. Therefore, while seeking a rapprochement with Iran was an early foreign policy goal of President Obama his 2009 letter to the Iranian leader is proof-positive of this assertion, as (Sobel 2001, Baum 2004a, Canes-Wrone 2006) suggests public opinion can constrain foreign policy. American public opinion was not ripe to be molded to such a foreign policy and electoral considerations for the American president did not allow until after 2012 actual attempts at rapprochement in the form of a nuclear deal. The political legacy for Obama as woven by administration myth makers is one where the president ended the costly war in Iraq and has avoided another one with Iran. On the former, this was calculated campaign rhetoric in 2012 and since March 2015 President Obama has publicly spoken on the positives of the Iran nuclear deal both in statements from the White House and in interviews with selected journalists ${ }^{10}$ and TV personalities as well as concentrating efforts on winning skeptical Democratic lawmakers while signaling acceptance of cooperation with Republican Senators; a move that is a concession that Congress will have the power to review a nuclear deal with Iran, reluctantly giving in to pressure from Republicans and some in his own party ${ }^{11}$.

It may be inferred that President Obama recognizes that the likelihood of a successful nuclear deal is delicate as well as the time sensitivity i.e. his presidency is almost over, Republicans hold the Congress and there is huge disagreement between Democrats and Republicans over the issue. As recent as May 22, 2015 in an extensive interview with Jeffrey Goldberg, Obama was honest, sharing his own anxieties about the nuclear talks ${ }^{12}$.

10 see Thomas Freidman's interview with President Obama: http://www.nytimes.com/ video/opinion/100000003612374/the-obama-doctrine-and-iran.html

11 see article in Reuters by Patricia Zengerle: http://www.reuters.com/ article/2015/04/14/us-iran-nuclear-congress-idUSKBN0N50AJ20150414 and the article published by The Hill: http://thehill.com/policy/defense/237754-corkercongress-must-be-clear-eyed-on-iran-deal

12 see Jeffrey Goldberg's interview inThe Atlantic, http://www.theatlantic.com/ international/archive/2015/05/obama-interview-iran-isis-israel/393782/ 


\section{Political Legacy}

Decades of scholarship have produced a favorable view that the president has had the most significant role in setting the policymaking agenda in Washington (Huntington 1965; Moe and Teel 1970). In fact, according to a study of agenda setting in Washington, Kingdon (1995: 23) found that the president is the single actor most capable of setting the agenda. Specifically linking public opinion favorably or not to a policy position, Baumgartner and Jones (1993: 241) concluded that the president can focus attention or change the motivations to such a great extent. Likewise, Bond and Fleisher (1990: 230) state that the greatest influence from the president is the agenda he pursues and the way it is packaged.

While there are critics to such held views, notably Edwards (1989) he admits that agenda setting is potentially an important strategic power of the president. The president attempts to shape public opinion via media manipulation ${ }^{13}$ and is achieved through briefings and background, interviews, press conferences with the president and efforts to coordinate news from the other branches of government. While research indicates a quantifiable inconsistency on success (Grossman and Kumar 1981; Maltese 1992; Rozell 1992, 1996) the importance of media on pushing presidential foreign policy agenda is nonetheless present. Media coverage of issue(s) increases public assessment of the issue and of the political figure. This then does indicate the degree that media may influence an issue (Cook, Tyler, et al. 1983; Dearing and Rogers 1996; Gonzenbach 1996; Iyengar, Peters, and Kinder 1982: 848-58; MacKuen and Coombs 1981, Winter and Eyal 1981).

According to Iyengar (1991: 2), "the themes and issues that are repeated in television news coverage become the priorities of viewers. Issues and events highlighted...become especially influential as criteria for evaluating public officials." Moreover, recent arguments point out that the media are engaged in a constant process of framing the news in response to competing requirements of both leaders and the public. Entman (2003) shows that the present alignment between the media, the public, and the administration is far less reliable and stable than the more rigid framework of the Cold War. He argues that "variations in cultural congruence, power, strategy, and motivation imply a continuum in the media-administration relationship, ranging from instances where the media essentially distribute the administration's message, at one end, to cases where they are quite critical and emphasize a contrary frame, at the other. This overall assessment is not reassuring for those who believe public opinion can or should positively influence foreign policy" (Baum and Potter, 2008: 55). Still, (Hallin 1986, Bennett 1990, Zaller \& Chiu 2000), political leaders influence the content of the news media. The framing of a leaders rhetoric has an independent causal effect

13 see Edwards and Wayne Presidential Leadership, chap. 5. 
on public perceptions of conflict characteristics, and through this process, on foreign policy. Here then is the foundation for building a sustainable political legacy of a leader.

It is necessary to consider briefly the falsification that domestic variables and leaders decisions often act in mutual support of each others in complementary interests and when not the case, it is the leader whose agenda setting or creating a frame impacts public opinion. To wit, is there a bias either from the American public or from the American president that can be applied to the hypothesis? Public opinion polling indicates that the answer is yes. While prior to 2008 there was general agreement that conflict with Iran was possible, since 2012 polling suggests over fifty percent agreement by the American public on support of rapprochement in the form of a nuclear deal. While bias is still considered, bias should be understood then as three distinct meanings. If applied to distorted reality usually observed in recollection from the news media, or to news that favors the content of a side over another, or the specific motivations and mindset of journalists who decide upon the content of the news.

The foreign policy decision to engage Iran in rapprochement and reasons for said decision has been documented within the news media both positive and hostile to the White House efforts and achieved therefore the definition of Positivism and serious empirical attention of bias (Niven, 2002) while also providing the basis for both singular and universal statements as observed by Popper ${ }^{14}$. Seeking a nuclear deal with Iran because American public opinion would not be favor of military action and such a deal's significance as "legacy-making" for President Obama fits both the idea that the existence of a particular thing i.e. public disapproval and the stated belief by the White House that no alternative other than the current nuclear framework deal is acceptable.

Popper's general notion of criticism applies, however it is necessary to reiterate that the agenda setting of the Obama administration since 2009 has been towards a balancing in the Middle East with Iran as a key player in this reorganization. Therefore, a nuclear deal with Iran is a good thing for the U.S. in the Middle East.

Moreover, the alternatives to a nuclear deal are unacceptable both to the leader and the public. Applying Popper's falsification test: a nuclear deal is the only option, what is an alternative? While American conservative political pundits and skeptical American allies, such as the Israeli Prime Minister, have indicated possible alternatives, those alternatives have effectively been refuted by the Obama administration and American public opinion, both of which as stated above are acting in mutual support.

14 Karl Popper, The Logic of Scientific Discovery. 


\section{Political Legacy in Foreign Policy}

How a leader is viewed by the public when out of office does not necessary correspond to the view of the leader while in office ${ }^{15}$. Likewise, policies taken during tenure in office may prove popular or conversely detrimental once the incumbent is out of office. Scholarly studies from Presidential historians point to this fact. ${ }^{16}$ In exploring how American public opinion either influences or is influenced by presidential decision making of American foreign policy it is important to remember that while the public is usually slow to demand accountability on foreign policy issues (Rosenau 1961, Zaller 1994a), it will become severe and swift if it finds that reality was stretched too far, for example President Johnson in Vietnam, 1968. Thus the costs are very high for leaders who provide, and the media that transmit, messages that overstretch the elasticity of reality, for example President George W. Bush in Iraq, 2004-2007. Therefore, for the current U.S. administration the prospect of rapprochement with Iran is significant. The argument for such negotiations has been framed. Progress has been made against partisan and international opposition and for President Obama such a deal would provide a legacy in American Foreign Policy along similar lines of President Nixon's rapprochement with China and detente with the Soviet Union. As to the short term, while Republicans hold majorities in both houses of the American Congress and there is disagreement over this issue, the White House has consistency framed the nuclear deal with Iran as the best option. In fact, the Obama administration has aggressively challenged detractors to provide a better alternative. However, there is a limit to the Iran deal. Congressional opposition from both Republicans and some Democrats has blunted the 'spin' that aides and representatives of the White House as "myth makers" have attempted upon both public opinion and other decision makers.

While, note-worthy opponents ${ }^{17}$ have pointed out that the president and his aides are overly optimistic and maintaining that any nuclear deal with Iran is bad, the

15 See the scholarly debate between John Lewis Gaddis and Melvyn Leffler over the importance of George W. Bush on U.S. foreign policy. Gaddis (2004) Surprise, Security and the American Experience that claims Bush is as important as President Roosevelt, or Leffler (2005) who claims in his article "9/11 and American Foreign Policy" that President Bush is not important comparing him instead with Ronald Reagan.

16 see Aaron David Miller, The End of Greatness: Why America Can't Have (and Doesn't Want) Another Great President (2014); Michael Beschloss, Presidential Courage: Brave Leaders and How they Changed America, 1789-1989 (2007).

17 See Israeli Prime Minister Benjamin Netanyahu March 3, 2015 speech to Congress, Charles Krauthammer April 9, 2015 Washington Post OpEd, and David Horovitz Times of Israel April 8, 2015 editorial. For arguably the best diplomatic reasons why not, see Henry Kissinger and George Schultz April 7, 2015 Wall Street Journal OpEd. 
domestic environment within the U.S. has provided the basis for such a rapprochement that President Obama seeks. The public debt in America, continued fall-out of the economic crisis, and reminders of the high causalities in Iraq and Afghanistan have made the American public weary of military campaigns abroad. Also, the public perception has changed from one in 2003-2004 where bombing Iran was unavoidable to one at present that is optimistic of a deal, though hesitant to completely trust Iran as polls suggest. So, one may argue that weariness of 10+ years of war have infiltrated the American home to produce sentiment in favor of diplomacy over military action; while also not to be discounted is the tendency of the American public to favor isolationist policies after a period of intervention ${ }^{18}$. Historically comparisons can be drawn from America's war in Vietnam and its aftermath to even American opinion after the First World War. However, the lessons of isolation were proven in World War II and American involvement in geopolitical affairs continues to be prevalent as the last forty years have shown.

Therefore, political legacy as it impacts decision making of the American president is a dependent variable worth consideration. Specific to the Obama presidency this is acute to the present negotiations between the Iran and the United States. The following views of U.S.-Iran nuclear negotiations indicates the level of importance amongst the American public since the issue was first framed. The study that was conducted from March 25-29, 2015 found that Americans favor a nuclear deal with Iran. But most respondents don't think an agreement will necessarily keep Iran from building a nuclear weapon. The Pew poll also found that 62 percent of Americans want Congress to have the final say on an agreement, with only 29 percent saying the president should. ${ }^{19}$

Recent polls show support for an Iran nuclear deal, but with wide variation as the five polls shown below indicate. Scheme No. 1: HUFFPOLLSTER

18 Charles Keglay and Eugene R. Wittkopf (1997) “American Foreign Policy: Pattern and Process" discuss isolationist and internationalist perspectives and unilateralist and multilateralist approach under internationalist perspective of American foreign policy.

19 Pew Research Center: U.S. Politics and Policy. March 30, 2015 found at http://www. people-press.org/2015/03/30/more-approve-than-disapprove-of-iran-talks-but-mostthink-iranians-are-not-serious/ 
Scheme No. 1: Polls Find Varying Support For Iran Nuclear Deal ${ }^{20}$

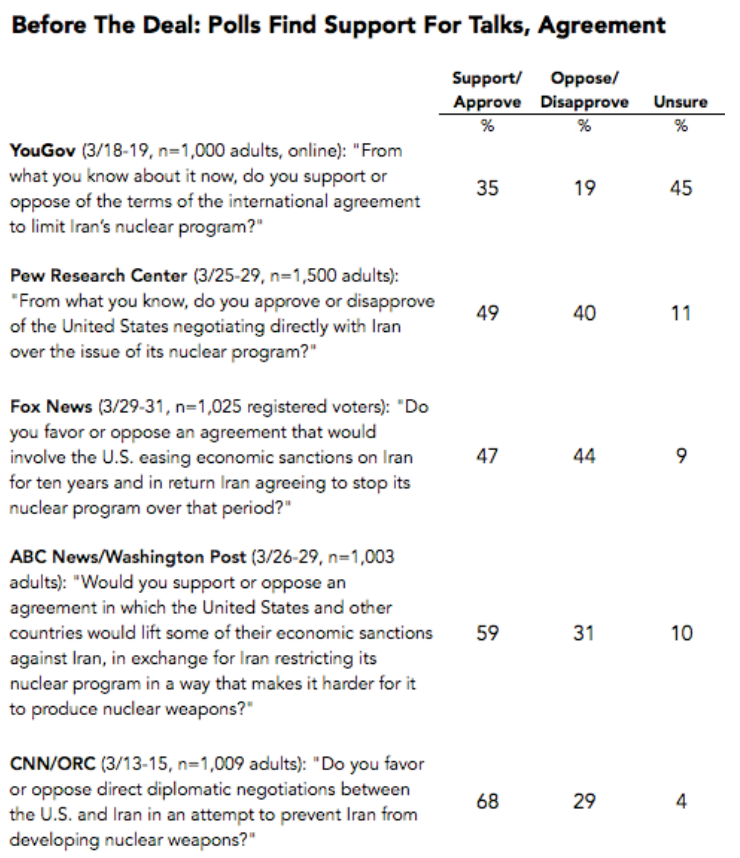

Source: HUFFPOLLSTER: Polls Find Varying Support For Iran Nuclear Deal ${ }^{21}$

An advisor to the Obama administration publicly stated, "this is probably the biggest thing that President Obama will do in his second term on foreign policy..."22 A accurate statement when quantitative evidence is imported to the frame. A December 3-8, 2013 Princeton Data Source polled a national sample of 2,001 adults with a margin of error of $+/-2.6$ percentage points on the the Interim Agreement finding 32\% approving of an agreement with $43 \%$ disapproving ${ }^{23}$, though a March $2015 \mathrm{CNN}$ poll found that $68 \%$ now favor negotiations.

However, while public opinion may support the agenda setting and framing that a leader produces for a specific foreign policy, the legacy may remain questionable

20 HUFFPOLLSTER: Polls Find Varying Support For Iran Nuclear Deal, April 3, 2015.

21 HUFFPOLLSTER: Polls Find Varying Support For Iran Nuclear Deal, April 3, 2015. 22 see David Nather, Michael Crowley, and Sarah Wheaton's article "Iran Nuclear Deal Breakthrough" at http://www.politico.com/story/2015/04/iran-nuclear-dealbreakthrough-116618.html\#ixzz3WF6SsomO

23 AIPAC. "American public opinion on Iran" at http://iraninfocus.aipac.org/learn/ polls-american-public-opinion-on-iran/ 
in relation to that frame the leader previously established. As the Washington Post/ $A B C$ News poll from March 26-29, 2015 above indicates, while public opinion is in favor of negotiations (59\%), there is a majority who do not think that Iran will be prevented from developing nuclear weapons. This indicates a continued source of framing on the part of the American leader. Moreover, it may expose the true intention of President Obama's efforts to attempt a synthesis of continued American engagement in the geopolitical important Middle East but not at the expense of American soldiers. Statements to such efforts have been made by President Obama before and offered as evidence in section one and section three. In short, not returning to isolation nor attempting a unilateral approach to solve the worry a Iranian nuclear program.

\section{POLL}

\section{Iran nuclear deal popular, but doubts about efficacy}

By nearly 2 to 1 the public supports a deal with Iran to lift economic sanctions and prevent the production of nuclear weapons. Despite the popularity of a deal, almost 6 in 10 think it will not eventually prevent Iran from developing weapons.

Q: Would you support or oppose an agreement in which the United States and other countries would lift major economic sanctions against Iran, in exchange for Iran restricting its nuclear program in a way that makes it harder for it to produce nuclear weapons?

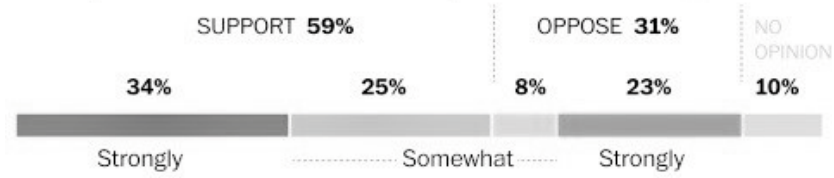

Q: How confident are you that such an agreement would prevent Iran from developing nuclear weapons?

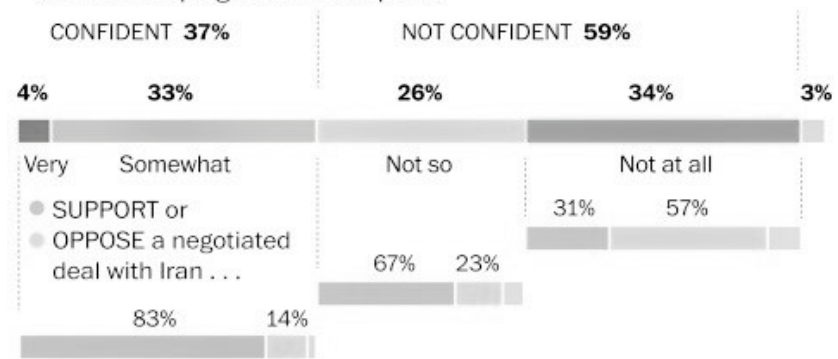

Numbers may not total 100 percent because of rounding.

SOURCE: This Washington Post-ABC News poll was conducted by telephone March 26-29

among a random sample of 1,003 adults. Interviews were conducted in English and Spanish on landlines and cell phones. Overall results have a margin of sampling error of plus or minus 3.5 percentage points. Sampling, data collection and tabulation by Abt-SRBI of New York. Full results and exact question wording and order is available at: www.washingtonpost.com/polls THE WASHINGTON POST 
This article has focused on the United States, due to the literature being centered within the American context. However, the dynamics described have implications for the relationship between the media, public opinion, and foreign policy in other nations as well. Indeed, literature is rapidly proliferating (e.g., Risse-Kappen 1991, Arian et al. 1992, Cohen 1995, Morgan \& Anderson 1999, Isernia et al. 2002). Additional research could occur along comparative lines on the relationship between foreign policy formulation process within and across regime types a positive relationship between the number of political parties and diversity content. For example the parliamentary make-up and decisions of leadership in Slovakia on NATO involvement in the 2014 Ukraine-Russian crisis over Crimea.

Additionally, it is important to discuss briefly that casual nexus of presidential decision making and polling results rather than only a coincidence or one of many intervening variables. While, intervening variables certainly add weight to decision making and agenda setting, it is not possible to state categorically that American public perception of military action in the Middle East, a war-weariness, was not in fact a reason for the Obama administrations current pursuit of a nuclear deal with Iran. But, public comments made by Barack Obama in $2007^{24}$ and as candidate for the presidency ${ }^{25}$ may refute this charge. It certainly supports the opinion of agenda framing that has been argued in this paper. While, intervening variables such as the petroleum industry, support of the military industrial complex and deeply personal (psychological) reason may explain Bush administration decision making in late 2002 and early 2003 to invade Iraq; intervening variables may prove difficult in this case with President Obama and Iran. As to both decision making and agenda setting of the Obama administration decision to engage Iran in a form of rapprochement with the proposed nuclear agreement as part of that has been shown in above paragraphs to be proposed policy pre-2009 and admittedly "legacy-setting" agenda post-2012 (see section 3). Therefore, while there is the possibility that public opinion polls and presidential decision making may be coincidental it is unlikely with evidence presented.

\section{Conclusion}

To the degree that public opinion, as domestic variable, influences a leaders decisionmaking in the area of foreign affairs is significant. Political leaders use public opinion polling to support government position(s) or in attempts to mold policy position(s) in the affirmative. Therefore, public opinion affects U.S. presidential foreign policy decisions and to the degree such decisions are used as the base for political legacy. Both

24 Democratic Presidential candidate Obama's interview on Meet The Press, November 11, 2007.

25 Democratic Presidential nominee Obama's Speech at AIPAC. June 4, 2008. 
domestic variables and leaders decisions often act in mutual support of each others in complementary interests and when not the case, it is the leader whose agenda setting or creating a frame impacts public opinion.

In the initial stages of a foreign policy event, when leaders hold a considerable advantage of information, public perception is very elastic. This frequently allows a president to dominate the so-called "framing war." Recent examples are George W. Bush, 2001-2004 in Afghanistan and Iraq, George Bush, 1991 in Iraq, Bill Clinton, 2000 Israeli-Palestinian peace and the historical example of Jimmy Carter, 1979 Iranian Hostage Crisis. As events unfold and further information is received by the public, the degree of elasticity declines, and a gap opens for alternative influence on public opinion. As was mentioned in the introduction, citizens are typically at a significant informational disadvantage vis-a vis leadership elites, compensating by employing heuristic cues that allow them to make reasoned judgments with small amounts of information. This is reflected in the polling data presented in this paper. Those heuristic cues however, are connected to a presidents framing an agenda i.e. President Obama's public comments and foreign policy initiative on a nuclear deal with Iran that can accepted within public perception on the grounds of effective arms-control structure.

Finally, the U.S.-Iranian nuclear negotiations as the domestic variables of public opinion, Congressional support, added with the external variable of weak allied diplomatic support i.e. Saudi Arabia, Israel, France for in agreement have produced a foreign policy initiative publicly supported and championed by the president with significant impact on political legacy. Whether in coming decades the view will remain favorable or be replaced remains to be seen. What is assured to remain accurate is the struggle between leaders disseminating information, as part of agenda setting, to an increasingly connected citizenry whose public opinion as a variable in forming foreign policy remains significant.

\section{References}

AMERICAN ISRAELI POLITICAL ACTION COMMITTEE. "American public opinion on Iran" [online], http://iraninfocus.aipac.org/learn/polls-american-publicopinion-on-iran/

ALDRICH, J., "Foreign Affairs and Issue Voting: Do Presidential Candidates 'Waltz before a Blind Audience'?" American Political Science Review 83,(1): 123-141. [online], http://jcr.sagepub.com/content/35/2/333.refs, 1989.

ANDERSON, J. Public Policy and Politics in America. North Scituate, MA: Duxbury, 1978.

ARIAN, A., SHAMIR, M., VENURA, R. "Public opinion and political changeIsrael and the Intifada". Comparative Politics. 24(3):317-34, In: KARSH, E. Israel 
at the Crossroads. London, British Academic Press, 1992.

BAUM, M. "Going private: presidential rhetoric, public opinion, and the domestic politics of audience costs in U.S. foreign policy crises". Journal of Conflict Resolution. 48:603-31. [online], http://www.hks.harvard.edu/fs/mbaum/ documents/GoingPrivate_JCR.pdf, 2004.

BAUM, M. \& POTTER. "The Relationships Between Mass Media, Public Opinion, and Foreign Policy: Toward a Theoretical Synthesis". Annual Review of Political Science. 11: 39-65. [online], http://www.hks.harvard.edu/fs/mbaum/documents/ BaumPotter_AnnualReview2008.pdf, 2008.

BAUMATNER, F., JONES, B. Agendas and Instability in American Politics. Chicago: University of Chicago Press, 1993.

BENNETT, W. "Toward a theory of press-state relations in the United States". Journal of Communications. 40:103-25. [online], http://www.researchgate.net/ profile/Lance_Bennett/publication/228018538_Toward_a_Theory_of_PressState_ Relations_in_the_United_States/links/02e7e530cb909a82ea000000.pdf, 1990.

BESCHLOSS, M. Presidential Courage: Brave Leaders and How they Changed America, 1789-1989. Simon \& Schuster, 2007.

BLUMENTHAU, M., EDWARDS-LEVY, A., VALENCIA, J. In: HUFFINGTON POST [online] HUFFPOLLSTER: Polls Find Varying Support For Iran Nuclear Deal [cit. 4.3.15] http://www.huffingtonpost.com/2015/04/03/iran-nuclear-dealpolls n 6999034.html, 2015.

BOND, J., Fleisher, R. The President in the International Arena. Chicago: Chicago University Press, 1990.

BRODY, R. 1991. Assessing the President: The Media, Elite Opinion, and Public Support. Stanford, CA: Stanford Univ. Press.

BROSIUS, H. "Perceptual Phenomena in the Agenda Setting Process" International Journal of Public Opinion Research 21 (2), 139-164. [online], http://oxfordindex. oup.com/view/10.1093/ijpor/edp019, 2009.

CANES-WRONE, B. Who Leads Whom? Presidents, Policy, and the Public. Chicago: University of Chicago Press, 2006.

COOK, F, TYLER, T, GOETZ, E., GORDON, M., PROTESS, D.,LEFF, D., and MOLOTCH, ML. "Media and Agenda Setting: Effects on the Public, Interest Group leaders, Policy Makers, and Policy." Public Opinion Quarterly 47 (Spring): 16-35. [online], http://poq.oxfordjournals.org/content/47/1/16.short, 1983.

COHEN, B. Democracies and Foreign Policy: Public Participation in the United States and the Netherlands. Madison: University of Wisconsin Press, 1995.

CNN In: USAToday/Gallup, [online] "Americans nervous about Iran" [cit 2.14.06] http://www.cnn.com/2006/POLITICS/02/13/poll.iran/, 2006.

DEARING, J., ROGERS, E. Agenda Setting. Thousand Oaks, CA: Saige, 1996. 
EDWARDS, G., WAYNE, S. Presidential Leadership. St. Martin's Press, 1999.

EDWARDS, G. At the Margins: Presidential Leadership of Congress. New Haven, CT: Yale University Press, 1989.

EICHENBERG, R. "Victory has many friends: U.S. public opinion and the use of military force". International Security. 30:[cit.140-77]. [online], http://www. mitpressjournals.org/doi/abs/10.1162/0162288054894616\#.VWDSq2DfJFI, 2005.

ENTMAN, R. Projections of Power: Framing News, Public Opinion, and U.S. Foreign Policy. Chicago: University of Chicago Press, 2003.

EVERST, P., FABER, A., "Public Opinion, Foreign Policy, and Democracy" World Politics. 43: [cit. 479-512]. [online], , (July, 1991).

FREIDMAN, T. Interview with President Obama [online], http://www.nytimes.com/ video/opinion/100000003612374/the-obama-doctrine-and-iran.html, 2015.

GADDIS, J.L. (2004) Surprise, Security and the American Experience. Harvard University Press, 2004.

GARTNER, S., SEGURA, G. "Race, casualties, and opinion in the Vietnam War." Journal of Politics. 62(1):115-46. [online], http:/www.jstor.org/ stable/2647600?seq=1\#page_scan_tab_contents, 1988.

GARTNER, S., SEGURA, G. "War, casualties and public opinion". Journal of Conflict. Resolution. 42(3):278-300. [online], http://jcr.sagepub.com/content/42/3/278. abstract,2000.

GOLDBERG, J. (May 21, 2015). The Atlantic. "Look ... It's My Name on This': Obama Defends the Iran Nuclear Deal." [online], http://www.theatlantic.com/ international/archive/2015/05/obama-interview-iran-isis-israel/393782/

GROSSMAN, M., KUMAR, M. Portraying the President. Baltimore, MD: John Hopkins University Press, 1981.

GONZENBACH, W. The Media, the President, and Public Opinion: A Longitudinal Analysis of the Drug Issue, 1984-1991. Mahwah, NJ: Lawrence Erlbaum, 1996. HALLIN, D. The "Uncensored War". Berkeley: Univ. Calif. Press, 1986.

HOLSI, O., ROSENAU, J. "The Domestic and Foreign Policy Beliefs of American Leaders," Journal of Conflict Resolution 32: [cit. 248-94]. [online], http://jcr. sagepub.com/content/32/2/248, (June 1988).

HOROVITZ, D. In: Times of Israel [online] "The Unfolding Farce of Obama's deal with Iran. Times of Israel [cit. 4.8.15],http://www.timesofisrael.com/the-unfoldingfarce-of-obamas-deal-with-iran/, 2015.

HUTCHESON, J., DOMKE, D., BILLEAUDEAUX, A., GARLAND, P. “U.S. national identity, political elites, and a patriotic press following September 11". [online], http://post.queensu.ca/ rosej/pols419/hutcheson.pdf, 2004.

HUNTINGTON, S. 1965. "Congressional Responses to the Twentieth Century." In: The Congress and America's Future, ed. TRUMAN, D.B. Englewood Cliffs, NJ: 
Prentice -Hall. pp.6-38. Amer Assembly; Revised edition, 1973.

ISERNIA, P., JUHASZ, Z., RATTINGER, H. "Foreign policy and the rational public in comparative perspective." Journal of Conflict Resolution. 46(2):201-24. [online] http://jcr.sagepub.com/content/46/2/201.refs, 2002.

IYENGAR, S. Is Anyone Responsible? Chicago: University of Chicago Press, 1991.

IYENGAR, S., PETERS, M., KINDER, D. 1982. "Experimental Demonstrations of the 'Not-So-Minimal' Consequences of Television News Programs." American Political Science Review 76 (December): 848-58. [online] http://www.uky. edu/ clthyn2/PS671/Iyengar_1982APSR.pdf

IYENGAR, S., REEVES, R. Do The Media Govern: Politicians, Voters, and Reporters in America. Thousand Oaks, CA: Sage, 1997.

JACOBSON, G. A Divider, Not a Uniter: George W. Bush and the American People. New York: Longman, 2006.

KEGLAY, C. and WITTKOPF, E. "American Foreign Policy: Pattern and Process" Boston, MA: Wadsworth Publishing, 1997.

KINGDON, J. Agendas, Alternatives, and Public Policies. 2d ed. Boston. Little Brown, 1995.

KISSINGER, H. and SCHULTZ, G. In: Wall Street Journal [online] "The Iran Deal and its Consequences" [cit. 5.7.15], http://www.wsj.com/articles/the-iran-dealand-its-consequences-1428447582, 2015.

KLAREVAS, L. "The "essential domino" of military operations: American public opinion and the use of force." International Studies Perspective. 3:417-37 [online], http:/onlinelibrary.wiley.com/doi/10.1111/1528-3577.t01-1-00107/ abstract, 2002.

KRAUTHAMMER, C. In Washington Post [online] "The Iran Deal: Anatomy of Disaster" [cit. 4.9.15], http://www.washingtonpost.com/opinions/the-iran-dealanatomy-of-a-disaster/2015/04/09/11bdf9ee-dee7-11e4-a1b8-2ed88bc190d2 story.html, 2015.

LARSON, E., SAVYCH, B. American Public Support for US Military Operations from Mogadishu to Baghdad: Technical Appendixes. Santa Monica, CA: RAND, 2005.

LEFFLER, M. In Foreign Policy, "Think Again: Bush's Foreign Policy" [cit,10.23.09], http://foreignpolicy.com/2009/10/23/think-again-bushs-foreignpolicy/,2009.

MACKUEN, M., COOMBS, S. More Than News. Beverly Hills, CA: Saige, 1981.

MALTESE, J. Spin Control: The White House Office of Communications and Management of Presidential News. Chapel Hill: University of North Carolina Press, 1992.

MILLER, A. D. The End of Greatness: Why America Can't Have (and Doesn't Want) 
Another Great President. Palgrave Macmillan Trade, 2014.

MOE, R., TEEL, S. “Congress as a Policymaker: A Necessary Reappraisal.” Political

Science Quarterly 85: [cit. 443-70]. [online], http://www.jstor.org/action/doBasicS earch?Query $=\mathrm{MOE} \% 2 \mathrm{C}+\mathrm{R} . \% 2 \mathrm{C}+\mathrm{TEEL} \% 2 \mathrm{C}+\mathrm{S} .+1970 .+$ “'Congress $+\mathrm{as}+\mathrm{a}+$ Polic ymaker $\% 3 \mathrm{~A}+\mathrm{A}+\mathrm{Necessary}+$ Reappraisal. $\$ \mathrm{acc}=\mathrm{off} \& \mathrm{wc}=\mathrm{on} \& \mathrm{fc}=\mathrm{off} \&$ group $=$ no ne, September, 1970.

MORGAN, P., ANDERSON, R. "Competing explanations of International Conflict" In: CHIOZZA, G., GOEMANS, H. 2011. Leaders and International Conflict. Cambridge University Press, 1999.

MUELLER, J. War Presidents and Public Opinion. New York: Wiley, 1973. NATHER, D., CROWLEY, M, and WHEATON, S. In: Politico [online], "Iran Nuclear Deal Breakthrough", [cit. 3-9.12.13], http:/www.politico.com/ story/2015/04/iran-nuclear-deal-breakthrough-116618.html\#ixzz3WF6SsomO, 2013.

NETANYAHU, B. In C-SPAN [online], "Israeli Prime Minister Address to Joint Meeting of Congress" [cit, 3.3.15 2015] http://www.c-span.org/video/?324609-2/ israeli-prime-minister-benjamin-netanyahu-address-congress, 2015.

NIVEN, D. The Search for Media Bias. Greenwood Publishing Group, 2002. OBAMA, B. Speech on Meet the Press. In NBC [online] "Obama on Iran" [cit 11.11.07] http://www.nbcnews.com/video/meet-the-press/21742059\#21742059, 2007.

OBAMA, B. Speech at AIPAC. In NPR [online] "President Obama's Speech at AIPAC. [cit. 6.4.08] http://www.npr.org/templates/story/story. php?storyId=91150432, 2008.

PEOPLE PRESS In: Pew Research Center [online] "Political Polarization in the American Public". [cit, 6.12.14], http://www.people-press.org/2014/06/12/ political-polarization-in-the-american-public/, 2014.

POLL In: Reuters/Zogby [online] "Americans Favor military action against Iran" [cit 8.22-25.06], http://www.reuters.com, 2006.

POPPER, K. The Logic of Scientific Discovery. [online], http://strangebeautiful.com/ other-texts/popper-logic-scientific-discovery.pdf Rutledge: London and New York, 2002.

POWLICK, P., KATZ, A. 1998. "Defining the American public opinion/foreign policy nexus”. International Studies Quarterly. 42: 29-61. In: D’ANIERI, P. International Politics: Power and Purpose in Global Affairs, Brief Edition, Boston, MA: Wadsworth, 2010.

RISSE-KAPPEN, T. "Public opinion, domestic structure, and foreign policy in liberal democracies." World Politics. 43(4): 479-512, [online] http://journals. cambridge.org/action/displayAbstract?fromPage $=$ online $\&$ aid $=7676192 \&$ fileId 
$=\mathrm{S} 0043887100019729,1991$.

ROSENAU, J. Public Opinion and Foreign Policy. New York: Random House, 1961.

ROZELL, M. The Press and the Ford Presidency. Ann-Arbor: University of Michigan Press, 1992.

ROZELL, M. The Press and the Bush Presidency. Westport, CT. Praeger, 1996.

SHAPIRO, R., PAGE, B. "Foreign Policy and the Rational Public," Journal of Conflict Resolution 32, no. 2, 211-47. [online] http://jcr.sagepub.com/ content/32/2/211.refs?patientinform-links=yes\&legid=spjcr;32/2/211, 1988.

SMITH, T. "The Polls: America's Most Important Problem, Part 1: National and International," Public Opinion Quarterly (1985) 49, no. 2. In: MCCORMICK, J., American Foreign Policy and Process. Cengage Learning, 2010.

SOBEL, R. The Impact of Public Opinion on U.S. Foreign Policy Since Vietnam. New York: Oxford University Press, 2001.

SMELTZ, D. In: Chicago Council on Global Affairs [online] "Foreign Policy In The New

Millennium, [26, 44], http://www.thechicagocouncil.org/sites/default/files/2012_ CCS_Report.pdf, 2012.

WHITE HOUSE. In: White House Press Secretary [online] "Remarks by the President in State of Union Address." [cit. 1.25.11] https://www.whitehouse.gov/ the-press-office/2011/01/25/remarks-president-state-union-address, 2011.

WHITE HOUSE. In: White House Press Secretary [online] "Remarks by the President in State of Union Address." [cit. 1.24.12] https://www.whitehouse.gov/ the-press-office/2012/01/24/remarks-president-state-union-address, 2012.

WINTER, J., Eyal, C. “Agenda-Setting for the Civil Rights Issue.” Public Opinion Quarterly 45 (Fall): 376-83. [online], http://poq.oxfordjournals.org/ content/45/3/376.short, 1981.

WOLFSFELD, G. Media and the Path to Peace. Cambridge, UK: Cambridge University Press, 2004.

WONG, K. In: The Hill. [online] "Corker and Congress Must Be Clear Eyed on Iran Deal" [cit 4.2.15] http://thehill.com/policy/defense/237754-corker-congress-mustbe-clear-eyed-on-iran-deal, 2015.

ZALLER, J. The Nature and Origins of Mass Opinion. New York: Cambridge University Press, 1992.

ZALLER, J. "Positive constructs of public opinion." Critical Studies Mass Communications. 11: [cit. 276-87]. [online] http://eric.ed.gov/?id=EJ489279, 1994.

ZALLER, J., CHIU, D. "Government's little helper: U.S. press coverage of foreign policy crises, 1946-1999." In: Decision-making in a Glass House, ed. BL 
Nacos, RY Shapiro, P Isernia, pp. 61-84. New York: Rowman \& Littlefield, 2000.

ZENGERIE, P. In: Reuters [online] "In Setback, Obama concedes Congress role in Iran deal", [cit 5.14.15] http://www.reuters.com/article/2015/04/14/us-irannuclear-congress-idUSKBN0N50AJ20150414, 2015.

Aaron T. Walter, Ph.D (2014), received his doctorate in International elations from the Faculty of Social Studies at Masaryk University. His research is on U.S. Foreign Policy formulated at the executive-level. He has also written on Comparative European Politics.

Aaron T. Walter, Ph.D (2014) Department of Politics and European Studies Faculty of Social Sciences Ss. Cyril \& Methodius University, Bucianska 4/A, 917 01, Trnava, Slovakia

E-mail: aaronwalter@gmail.com 